\title{
RENSTRA SISTEM INFORMASI PENGUKURAN KINERJA DOSEN DENGAN IT BALANCED SCORECARD
}

\author{
I Gede Juliana Eka Putra' ${ }^{1)}$ Anak Agung Gede Agung Wedhatama Pemayun ${ }^{2)}$ \\ Program Studi Teknik Informatika ${ }^{1) 2}$ \\ STMIK Primakara, Denpasar, Bali ${ }^{12}{ }^{2}$ \\ gedejep@primakara.ac.id ${ }^{1)}$
}

\begin{abstract}
Performance measurement is very essential for universities that want to stay superior and compete in national and global. With the lack of research and community service carried out by STMIK Primakara lecturers, institutionally, these problems have an impact on achieving the campus vision and mission, especially in STMIK Primakara lecturers' quality assurance. Strategic planning of information systems for measuring lecturer performance is carried out using the IT Balanced Scorecard perspective approach, namely company contribution, operational perfection, user orientation and future orientation. The results of this study in the perspective of organizational contributions have 3 strategic objectives, namely lecturer honorarium, research budget, community service, lecturer development, publications, internal / external grants. In the orientation perspective the user has 2 strategic goals, namely increasing service to students, increasing service to the community. In the perspective of operational excellence, there are 2 strategic objectives, namely the improvement of the teaching and learning process by lecturers, the present learning content by the lecturers. In the perspective of future orientation, it has 5 strategic objectives, namely research, community service, scientific publications, further study of lecturers, development of lecturer competencies. In addition to producing 12 strategic objectives, in this study also produced 27 key performance indicators that will be used as lecturer performance at STMIK Primakara Keywords : Strategic Plan, Information System, Lecturer Performance, IT Balanced Scorecard
\end{abstract}

\begin{abstract}
ABSTRAK
Pengukuran kinerja merupakan hal yang sangat essensial bagi perguruan tinggi yang ingin tetap unggul dan bersaing dalam kancah nasional maupun global. Dengan minimnya jumlah penelitian dan pengabdian kepada masyarakat yang dilakukan oleh dosen STMIK Primakara, secara kelembagaan, permasalahan tersebut berdampak pada pencapaian visi dan misi kampus khususnya pada penjaminan mutu dosen STMIK Primakara. Perencanaan strategis sistem informasi pengukuran kinerja dosen ini dilakukan dengan pendekatan perspektif IT Balanced Scorecard, yaitu kontribusi perusahaan, kesempurnaan operasional, orientasi pengguna dan orientasi masa depan. Hasil dari penelitian ini dalam perspektif kontribusi organisasi memiliki 3 sasaran strategis, yaitu honorarium dosen, anggaran untuk penelitian, pengmas, pengembangan dosen, publikasi, dana hibah internal/eksternal. Dalam perspektif orientasi pengguna memiliki 2 sasaran startegis, yaitu peningkatan pelayanan kepada mahasiswa, peningkatan pelayanan kepada masyarakat. Dalam perspektif keunggulan operasional memiliki 2 sasaran startegis, yaitu peningkatan proses belajar mengajar oleh dosen, konten pembelajaran yang kekinian oleh dosen. Dalam perspektif orientasi dimasa depan memiliki memiliki 5 sasaran startegis, yaitu penelitian, pengabdian masyarakat, publikasi ilmiah, studi lanjut dosen, pengembangan kompetensi dosen. Selain menghasilan 12 sasaran strategis, dalam penelitian ini pula menghasilkan 27 key performance indicator yang akan digunakan sebagai kinerja dosen di STMIK Primakara
\end{abstract}

Kata Kunci: Renstra, Sistem Informasi, Kinerja Dosen, IT Balanced Scorecar 


\section{PENDAHULUAN}

Perguruan tinggi merupakan salah satu lembaga pendidikan yang berperan penting dalam menyediakan sumber daya manusia berkualitas untuk pembangunan bangsa oleh karena itulah sebagai suatu perguruan tinggi perlu meningkatkan kualitas kinerjanya. Untuk mewujudkan hal tersebut, perguruan tinggi memerlukan kemampuan pengelolaan, pengembangan, perbaikan dan penyempurnaan kegiatan pendidikan sekaligus mengantisipasi perkembangan kelembagaan dengan menggunakan prinsip-prinsip manajemen modern yang berorientasi pada mutu untuk menghasilkan sumber daya manusia yang kompetitif berstandar nasional maupun internasional

Salah satu yang memegang peranan penting untuk menghasilkan sumber daya manusia yang memiliki pengetahuan, keahlian dan keterampilan pada bidang teknologi informasi adalah dosen. Dalam UU No 14/2005 tentang guru dan dosen, dosen dinyatakan sebagai pendidik profesional dan ilmuan dengan tugas utama mentransformasikan, mengembangkan, menyebarluaskan ilmu pengetahuan, teknologi dan seni melalui pendidikan, penelitian dan pengabdian pada masyarakat. Banyak faktor yang mempengaruhi baik secara langsung maupun tidak langsung. Motivasi merupakan salah satu yang mempengaruhi produktivitas secara tidak langsung sedangkan kinerja dapat mempengaruhi secara langsung. Rendahnya produktifitas dosen merupakan salah satu penyebab tidak tercapainya tujuan perguruan tinggi. Kondisi tersebut dapat diumpamakan dalam bentuk tidak berjalannya tri dharma perguruan tinggi. Keadaan ini menunjukkan bagaimana rendahnya motivasi kerja dosen dan kinerja yang berpengaruh pada produktivitas.

Sekolah Tinggi Manajemen Informatika dan Komputer (STMIK) Primakara sebagai salah satu lembaga pendidikan tinggi komputer di propinsi Bali yang berdiri pada tanggal 27 September 2013 dengan izin berdasarkan SK Kementerian Pendidikan dan Kebudayaan Dirjen Pendidikan Tinggi Nomor 458/E/O/2013. STMIK Primakara memiliki tiga Program Studi yaitu S-1 Sistem Informasi. S-1 Sistem Informasi Akuntansi, dan S-1 Teknik Informatika dengan jumlah mahasiswa sebanyak 257 orang dan jumlah dosen tetap sebanyak 29 orang. Sebagai lembaga pendidikan tinggi yang baru berumur 3 tahun, STMIK
Primakara mengalami kendala dalam pengukuran kinerja dosennya. Aspek tri dharma perguruan tinggi yaitu dalam hal pengajaran, penelitian dan pengabdian masyarakat yang seharusnya menjadi tugas pokok dosen STMIK Primakara sampai saat ini belum berjalan dengan baik. Hal tersebut dikarenakan belum adanya indikator pengukuran kinerja dosen yang jelas yang dimiliki oleh STMIK Primakara, selain itu jumlah sumber daya dosen yang terbatas saat ini mengakibatkan seluruh dosen STMIK Primakara memegang jabatan struktural di level manajemen. Kondisi ini mengakibatkan beban kerja dosen menjadi tinggi karena dituntut untuk melakukan kegiatan administrasi yang tentu saya akan mempengaruhi kewajiban dosen dalam tri dharma perguruan tinggi. Hal tersebut berdampak pada masih kurangnya semangat dosen untuk melakukan kegiatan penelitian dan pengabdian kepada masyarakat. Dengan minimnya jumlah penelitian dan pengabdian kepada masyarakat yang dilakukan oleh dosen STMIK Primakara, maka akan menghambat dalam pengajuan jabatan fungsional akademik untuk setiap dosen. Secara kelembagaan, permasalahan tersebut berdampak pada pencapaian visi dan misi kampus khususnya pada penjaminan mutu dosen STMIK Primakara. Secara umum manfaat penilaian kinerja adalah (1) untuk mengelola operasi organisasi secara efektif dan efisien melalui pemotivasian personel secara maksimal; (2) membantu pengambilan keputusan yang berkaitan dengan penghargaan personel; (3) mengidentifikasi kebutuhan dan pengembangan personel; (4) menyediakan suatu dasar untuk mendistribusikan penghargaan ${ }^{[1]}$.

Perencanaan strategis sistem informasi dibutuhkan untuk menyesuaikan gerak langkah organisasi dengan sistem informasi yang pas dengan irama perkembangan organisasi dan mampu untuk memenuhi kebutuhan sistem informasi organisasi di masa datang ${ }^{[2]}$. Dari latar belakang diatas dan mengingat pentingnya kinerja dosen untuk menjaga kualitas lulusan serta meningkatkan daya saing maka diperlukan suatu perencanaan strategis sistem informasi pengukuran kinerja dosen di STMIK Primakara. Perencanaan strategis sistem informasi pengukuran kinerja dosen ini dilakukan 
dengan pendekatan IT Balanced Scorecard. Pendekatan IT Balanced Scorecard akan menganalisis kinerja dosen dari empat perspektif, yaitu kontribusi perusahaan, kesempurnaan operasional, orientasi pengguna dan orientasi masa depan, sehingga dari hasil penilaian tersebut dapat digunakan untuk merumuskan renstra pengukuran kinerja dosen di STMIK Primakara.

\section{TINJAUAN PUSTAKA}

\section{Pengukuran Kinerja}

Dalam menyelenggarakan pendidikan, salah satu upaya untuk meningkatkan kualitas proses belajar mengajar adalah dengan meningkatkan kinerja dosen ${ }^{[3]}$. Dalam upaya meningkatkan kinerja dosen, diperlukan suatu sistem penilaian kinerja dosen yang dapat mengukur apakah dosen sudah memenuhi standar yang dibutuhkan oleh lembaga pendidikan. Hasil sistem penilaian kinerja dosen menjadi bahan evaluasi bagi manajemen berkaitan dengan keputusan dalam upaya peningkatan kinerja dosen.

Pengukuran kinerja merupakan kegiatan pengukuran yang dilakukan dalam value chain perusahaan yang tujuannya adalah untuk mendapatkan informasi mengenai kondisi kinerja atau kondisi dari suatu perencanaan, juga pengukuran kinerja dapat memberikan umpan balik bagi perusahaan untuk mengetahui bagian-bagian dalam perusahaan yang perlu mengalami penyesuaian. Penilaian kinerja mengacu pada suatu system formal dan terstruktur yang digunakan untuk mengukur, menilai dan mempengaruhi sifat-sifat yang berkaitan dengan pekerjaan, perilaku dan hasil. Dengan dimikian, penilaian prestasi adalah merupakan hasil kerja personil dalam lingkup tanggung jawabnya ${ }^{[4]}$. Penilaian kinerja membutuhkan standar yang jelas yang dijadikan tolak ukur atau patokan terhadap kinerja yang akan diukur. Standar yang dibuat harus berhubungan dengan jenis pekerjaan yang akan diukur dan hasil yang diharapkan. Ada empat hal yang harus diperhatikan dalam menyusun standar penilaian kinerja yaitu validity, agreement, realism, dan objectivity ${ }^{[3]}$.

a. Validity adalah keabsahan standar tersebut sesuai dengan jenis pekerjaan yang dinilai. Keabsahan yang dimaksud di sini adalah standar tersebut memang benar-benar sesuai atau relevan dengan jenis pekerjaan yang akan dinilai tersebut. b. Agreement berarti persetujuan, yaitu standar penilaian tersebut disetujui dan diterima oleh semua pegawai yang akan mendapat penilaian.

c. Realism berarti standar penilaian tersebut bersifat realistis, dapat dicapai oleh para pegawai dan sesuai dengan kemampuan pegawai.

d. Objectivity berarti standar tersebut bersifat obyektif, yaitu adil, mampu mencerminkan keadaan yang sebenarnya tanpa menambah atau mengurangi kenyataan dan sulit untuk dipengaruhi oleh bias -bias penilai.

Kinerja dosen pada suatu perguruan tinggi merupakan perilaku nyata yang ditampilkan setiap dosen sebagai prestasi kerja yang dihasilkan oleh dosen tersebut sesuai dengan peranannya. Untuk dapat menentukan kualitas kinerja dosen perlu adanya criteria yang jelas. Kinerja dosen merupakan suatu hal yang sangat penting dalam upaya lembaga perguruan tinggi untuk mencapai tujuanya. Di dalam dunia yang kompetitip, setiap perguruan tinggi memerlukan kinerja dosen yang tinggi. Pada saat yang bersamaan, dosen sebagai ujung tombak suatu perguruan tinggi memerlukan umpan balik dari lembaga atas hasil kerja mereka sebagai panduan bagi perilaku mereka di masa yang akan datang. Umpan balik terhadap kinerja dosen dapat dilakukan melalui evaluasi kinerja. Penilaian kinerja dosen merupakan suatu proses dimana lembaga melakukan evaluasi atau menilai kinerja dosen atau mengevaluasi hasil pekerjaan dosen. Penilaian yang dilakukan terhadap dosen berbasis pada pengawasan, artinya penilaian yang dilakukan terhadap dosen tidak saja ditujukan untuk menilai kinerja, juga sekaligus berfungsi untuk mengawasi dosen dalam melaksanakan tugas pokoknya, yaitu kegiatan pendidikan dan pengajaran, penelitian, dan pengabdian pada masyarakat.

\section{Strategi Sistem Informasi}

Sistem adalah kumpulan komponen yang saling berhubungan yang berfungsi bersama-sama untuk mencapai hasil yang diinginkan Menurut Turban ${ }^{[5]}$. Disebutkan bahwa sistem dibagi menjadi tiga bagian yang berbeda : input, proses, dan output. Bagianbagian tersebut dikelilingi oleh sebuah lingkungan dan sering melibatkan sebuah mekanisme umpan balik. Selain itu, pengambil keputusan juga dianggap sebagai bagian dari sis- 
tem. Setiap sistem biasanya memiliki beberapa tujuan yang dibagi dalam subsistem yang secara keseluruhan bertujuan untuk memberikan kontribusi dalam pencapaian tujuan sistem secara keseluruhan.

Penerapan sistem informasi akan bermanfaat jika penerapannya sesuai dengan tujuan, visi dan misi perusahaan dengan menetapkan strategi sistem teknologi informasi yang selaras dengan strategi bisnis. Dalam industri usaha jasa, sistem informasi merupakan senjata yang paling penting dalam memenangkan persaingan usaha, mengingat informasi merupakan aset yang sangat strategis. Hal tersebut juga dapat mendukung rencana dan pengembangan bisnis perusahaan yang nantinya akan memberikan nilai tambah berupa competitive advantage dalam persaingan bisnis ${ }^{[6]}$.

Strategi sistem informasi adalah strategi yang mendefinisikan kebutuhan organisasi atau perusahaan terhadap informasi dan sistem yang mendukung keseluruhan strategi bisnis yang dimiliki organisasi tersebut ${ }^{[7]}$. Strategi sistem informasi adalah operasi pendukung atau proses manajemen yang menyediakan bagi perusahaan produk strategis, jasa dan kemampuan untuk keunggulan kompetitif ${ }^{[8]}$.

\section{Perencanaan Strategis Sistem Informasi}

Peran perencanaan strategis sistem informasi menjadi penting dalam menentukan keberhasilan suatu lembaga pendidikan. Dengan perencanaan strategi sistem informasi diharapkan memberikan arahan, dan konsentrasi pada usahanya agar mencapai target ${ }^{[9]}$. Sistem dapat didefinisikan sebagai sebuah set elemen terintegrasi yang dioperasikan masing-masing dengan kemampuan eksplisit yang telah ditentukan dan dibatasi, bekerja secara sinergis untuk memberikan nilai tambah.

Dalam memasuki lingkungan bisnis yang kompetitif, manajemen sistem informasi yang baik merupakan faktor penting yang harus diperhatikan. Perencanaan stretegis yang baik, dapat meningkatkan efesiensi dan efektifitas dalam proses bisnis, memberikan nilai tambah berupa competiteve advantage dalam persaingan bisnis, serta mampu meningkatkan kinerja dan menumbuhkan daya saing yang berkelanjutan (sustainable competitive) ${ }^{[10]}$.

Dalam perencanaan strategis sistem informasi dibutuhkan untuk mempersiapkan organisasi dalam merencanakan pemakaian teknologi dan sistem informasi untuk organi- sasinya $^{[2]}$. Perencanaan tersebut sangat dibutuhkan untuk menyesuaikan gerak langkah organisasi dengan sistem informasi yang pas dengan irama perkembangan organisasi dan mampu untuk memenuhi kebutuhan sistem informasi organisasi di masa datang.

Penyelarasan antara strategi bisnis dan sistem informasi merupakan salah satu faktor dalam menghadapi persaingan. Perencanaan strategis sistem informasi digunakan untuk menyelaraskan antara kebutuhan strategi bisnis dan strategi sistem informasi untuk mendapatkan nilai tambah dari suatu organisasi dari segi keunggulan kompetitif ${ }^{[11]}$. Proses identifikasi kebutuhan informasi perencanaan strategis sistem informasi dimulai terlebih dahulu dari lingkungan organisasi yang memuat visi, misi, dan tujuan organisasi, dilanjutkan kepada identifikasi terhadap lingkungan internal dan eksternal organisasi, serta identifikasi internal dan eksternal lingkungan organisasi, kemudian proses penentuan peluang sistem informasi dapat dilaksanakan ketika kebutuhan informasi dari tujuan organisasi telah semuanya teridentifikasi.

\section{IT Balanced Scorecard}

Balanced Scorecard terdiri dari dua kata : kartu skor (scorecard) dan berimbang (balanced). Kartu skor adalah kartu yang digunakan untuk mencatat skor hasil kinerja suatu organisasi atau skor individu ${ }^{[12]}$. Kartu skor juga dapat digunakan untuk merencanakan skor yang hendak diwujudkan di masa depan. Melalui kartu skor, skor yang hendak diwujudkan organisasi/individu di masa depan dibandingkan dengan hasil kinerja sesungguhnya. Hasil perbandingan ini digunakan untuk melakukan evaluasi atas kinerja organisasi/individu yang bersangkutan. Kata berimbang dimaksudkan untuk menunjukkan bahwa kinerja organisasi/individu diukur secara berimbang dari dua aspek: keuangan dan non keuangan, jangka pendek dan jangka panjang, internal dan eksternal.

Balanced Scorecard pertama kali dipublikasikan dalam artikel Robert S. Kaplan dan David. P. Norton di Harvaard Business Review tahun 1992 dalam sebuah artikel yang berjudul "Balanced Scorecard - Measures that Drive Performance" Intinya scorecard terdiri atas tolok ukur keuangan yang menunjukkan hasil dari tindakan yang diambil sebagaimana ditunjukkan pada tiga perspektif to- 
lak ukur operasional lainnya : kepuasan pelanggan, proses internal dan kemampuan berorganisasi untuk belajar dan melakukan perbaikan $^{[13]}$.

Balanced Scorecard lebih dari sekedar sistem pengukuran taktis atau operasional $^{[14]}$. Perusahaan yang inovatif menggunakan scorecard sebagai sebuah sistem manajemen strategis, untuk mengelola strategi jangka panjang. Perusahaan menggunakan fokus pengukuran scorecard untuk menghasilkan berbagai proses manajemen penting seperti memperjelas dan menerjemahkan visi dan strategi, mengkomunikasikan dan mengaitkan berbagai tujuan dan ukuran strategis, merencanakan, menetapkan sasaran dan menyelaraskan berbagai inisiatif strategis, meningkatkan umpan balik dan pembelajaran strategis. Dalam perkembangannya Balanced Scorecard lebih dimanfaatkan sebagai alat yang efektif untuk perencanaan strategis, yaitu sebagai alat untuk menterjemahkan misi, visi, peran kunci, faktor penentu keberhasilan, tujuan, tolok ukur dan target kinerja serta tindakan perbaikan yang komprehensip, koheren, terukur dan berimbang.

IT Balanced Scorecard yang merupakan modifikasi dari Balanced Scorecard Tradisional ${ }^{[15]}$. Pada tahun 1997, Van Grembergen dan Van Bruggen mengadopsi balanceed scorecard untuk dipergunakan pada Departemen Teknologi Informasi, sehingga terjadi perubahan perspektif pada model tradisional dan model IT Balanced Scorecard ${ }^{[16]}$. Dalam pandangan mereka karena Departemen Teknologi Informasi merupakan penyedia layanan internal maka perspektif yang digunakan harus diubah dan disesuaikan. Dengan melihat bahwa pengguna mereka adalah pegawai internal dan kontribusi mereka dinilai berdasarkan pandangan pihak manajemen maka mereka mengajukan perubahan. Selain Itu, alasan mereka melakukan perubahan tersebut adalah karena unit IT dalam suatu perusahaan biasanya melayani kebutuhan internal perusahaan dan proyek yang dilaksanakan biasanya dikerjakan untuk kepentingan unit perusahaan secara keseluruhan ${ }^{[17]}$.

Penerapan IT Balanced Scorecard untuk pengukuran kinerja $I T$ dengan studi kasus pada Canadian Financial Group, dimana mereka membahas penggunaan framework IT Balanced Scorecard dalam pengukuran kinerja IT suatu perusahaan. Selain itu dalam jurnal tersebut juga dibahas mengenai pengukuran yang digunakan dan juga tolok ukur dalam pengukuran yang dilakukan, sehingga pada akhirnya akan didapatkan tingkat kinerja dari $I T$ dari pandangan empat perspektif IT Balanced Scorecard. Disamping itu dengan maturity model yang diusulkan oleh Grembergen, dapat dilihat sejauh mana tingkat atau level implementasi dari IT Balanced Scorecard di perusahaan. Penerapan IT Balanced Scorecard dalam mengukur keberhasilan atau kinerja dari IT Governance, Wim Van Grembergen mengungkapkan penggunaan dari IT Balanced Scorecard yang dapat menyelaraskan IT Governance dengan strategi perusahaan, juga sebagai metode untuk memantau keberhasilan penerapan atau kinerja dari IT Governance di suatu perusahaan.

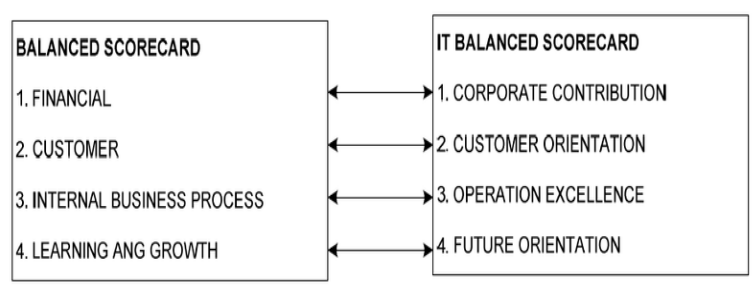

\section{Gambar 2.1 Perspektif BSC Tradisional terhadap IT Balanced Scorecard}

Dari empat perspektif Balanced Scorecard kemudian dimodifikasi menjadi kontribusi bisnis, oreantasi pengguna atau pelanggan, kesempurnaan operasional dan orientasi masa depan. Adapun kelebihan dari penggunaan IT Balanced Scorecard adalah :

a. Perusahaan dapat mengembangkan analisis kinerja IT mereka secara luas dan spesifik yaitu beberapa perspektif orientasi pelanggan atau pengguna, kontribusi perusahaan, kesempurnaan operasional dan orientasi masa depan.

b. Meningkatkan efektifitas proyek IT untuk memenuhi kebutuhan strategi perusahaan.

c. Meningkatkan hubungan dan dialog antara IT dengan perusahaan serta unit bisnis pelanggan.

d. Memberikan pengertian yang lebih luas dan penerimaan dari inisiatif IT melalui komunikasi yang jelas dan komprehensif.

e. Teknologi lebih diposisikan untuk meningkatkan keunggulan bersaing.

Untuk menganalisis kinerja perusahaan berkaitan dengan tata kelola IT dapat dilakukan dengan Information Technology $\mathrm{Ba}$ - 
lanced Scorecard (IT Balanced Scorecard) yang merupakan suatu sistem manajemen, pengukuran dan pengendalian yang secara cepat, tepat dan komprehensif dapat memberikan pemahaman kepada Pimpinan tentang potret dan pengembangan teknologi informasi di institusinya Perspektif dalam mengevaluasi kinerja IT pada Balanced Scorecard ${ }^{[18]}$ yaitu :

a. Kontribusi Organisasi (Corporate Contribution). Perspektif ini berdasarkan pandangan dari manajemen eksekutif, direktur shareholder. Evaluasi IT yang dilakukan terdiri dari valuasi secara finansial jangka pendek dan evaluasi jangka panjang terhadap proyek dan fungsi IT. Nilai tambah dari teknologi informasi melibatkan resiko dalam pencapaiannya. Penggunaan tolak ukur finansial sebagai satu-satunya pengukur kinerja organisasi memiliki beberapa kelemahan, antaranya yang pertama; dapat mendorong manajer untuk mengambil tindakan jangka pendek dengan mengorbankan kepentingan jangka panjang. Hal ini akan mengakibatkan kinerja keuangan meningkat untuk jangka pendek tetapi dalam jangka panjang justru akan merugikan. Kedua ; diabaikannya aspek pengukuran nonfinansial termasuk intangible asset dan intagible benefit, pada umumnya akan memberikan pandangan yang keliru bagi manajer mengenai situasi dan kondisi organisasi di masa sekarang dan di masa mendatang. Ketiga ; tolak ukur kinerja keuangan bersifat masa lalu dan tidak sepenuhnya menuntun organisasi ke arah tujuan di masa mendatang.

b. Orientasi pengguna (User Orientation). Perspektif ini mengevaluasi kinerja IT berdasarkan cara pandang pelanggan terhadap unit bisnis yang ada. Dalam hal ini perusahaan harus melakukan identifikasi pelanggan dan segmen pasar yang akan dimasuki agar dapat menyelaraskan berbagai ukuran pelanggan seperti : kepuasan, loyalitas, retensi, akuisisi dan profitabilitas, terhadap pelanggan sendiri dan segmen pasar perusahaan. Jadi jika pelanggan sebagai pengguna tidak merasa puas maka akan banyak keluhan atau bahkan akan menurunkan kinerjanya di masa yang akan datang. Secara umum, perspektif ini memiliki dua kelompok pengukuran yaitu kelompok utama dan kelompok pendorong kinerja. Kelompok utama terdiri dari ukuran pangsa pasar, retensi pelanggan, akuisisi pelanggan, kepuasan pelanggan dan profitabilitas pelanggan. Kelompok pendorong kinerja merupakan faktor pendorong kinerja hasil pelanggan yang menawarkan proposisi nilai pelanggan yang diberikan organisasi. Proposisi nilai ini menyatakan atribut yang diberikan organisasi kepada produk dan jasanya untuk menciptakan loyalitas dan kepuasan pelanggan.

c. Keunggulan Operasional (Operational Excellence). Perspektif ini menilai kinerja IT berdasarkan cara pandang manajemen IT itu sendiri dan lebih lagi adalah pihak yang berkaitan dengan audit dan pihak yang menetapkan aturan-aturan yang digunakan. Keunggulan operasional suatu organisasi dapat dilihat pada operasi bisnis internal yang terjadi, yang dapat dibagi ke dalam tiga hal yaitu inovasi, operasional, dan pelayanan purna jual. Inovasi dalam hal ini untuk menggali pemahaman tentang kebutuhan laten dari pelanggan dan menciptakan produk dan jasa yang mereka butuhkan. Proses inovasi dilakukan dan setelah melalui serangkaian tes dan telah memenuhi syarat-syarat pemasaran dan dapat dikomersilkan maka produk atau jasa tersebut diperkenalkan kepada pelanggan. Aktivitas ini merupakan akitvitas penting yang berlangsung untuk jangka panjang sehingga menentukan kesuksesan organisasi dimasa sekarang dan dimasa mendatang. Operasional merupakan proses dalam pembuatan dan penyampaian produk atau jasa. Dalam proses ini pengukuran yang terkait dapat dikelompokkan pada waktu, kualitas dan biaya. Pelayanan purna jual dimulai pada saat produk atau jasa sudah terjual atau digunakan. Organisasi dapat mengukur apakah upayanya dalam proses ini telah sesuai dengan harapan pelanggan. Pengukuran pada proses ini dapat menggunakan tolak ukur yang bersifat kualitas, biaya dan waktu.

d. Orientasi dimasa depan (Future Orientation). Perspektif ini menilai kinerja IT berdasarkan cara pandang dari departemen itu sendiri. Pada perspektif ini akan menyiapkan infrastruktur organisasi yang memungkinkan tujuan pada tiga perspektif lainnya dapat dicapai. Kemampuan orga- 
nisasi untuk dapat menghasilkan produk atau jasa di masa mendatang dengan kemampuan layanan yang memuaskan harus dipersiapkan mulai dari saat ini. Pihak manajemen harus dapat memperkirakan tren di masa mendatang dan membuat langkahlangkah persiapan dalam menghadapinya. Beberapa hal yang dapat diperhatikan secara khusus dalam penanganan di masa depan antara lain kapabilitas pekerja dan kapabilitas sistem informasi. Dalam hal kapabilitas pekerja, perencanaan dan pelaksanaan pelatihan kembali pegawai yang dapat menjamin kecerdasan dan kreativitasnya dapat dimobilisasi untuk mencapai tujuan organisasi. Faktor pendorong yang penting dalam meningkatkan kapabiltas pekerja diantaranya :

a) Kompetensi Staf ; Dibutuhkannya pelatihan ulang dapat dipandang dalam dua dimensi yaitu : tingkat pelatihan yang dibutuhkan dan persentase tenaga kerja yang membutuhkan pelatihan ulang. Bila tingkat pelatihan ulang pekerja rendah, latihan dan pendidikan normal sudah mencukupi bagi organisasi untuk mempertahankan kapabilitas kerja. Dalam hal ini pelatihan ulang bukan merupakan prioritas dalam IT Balanced Scorecard. Hal yang berbeda berlaku untuk situasi sebaliknya, dimana pekerja membutuhkan latihan khusus.

b) Infrastruktur Teknologi ; Mencerminkan kekuatan tepat guna dan sasaran dari teknologi yang digunakan organisasi dalam pencapaian tujuan-tujuannya. Faktor-faktor yang dapat dimasukkan dalam kategori ini antara lain : penggunaan teknologi strategis, penggunaan database strategis, pengalaman yang dimiliki dan paten atau hak cipta.

c) Ilmu untuk bertindak ; Faktor pendorong ini biasanya diakibatkan oleh situasi dan kondisi tertentu yang tercipta dalam pelaksanaan proses-proses bisnis maupun dalam pencapaian tujuan strategis organisasi. Faktor-faktor yang termasuk dalam kategori ini antara lain : fokus strategi, pemberdayaan staf, moral pekerja dan kerjasama tim.

Sedangkan dalam hal kapabilitas Sistem Informasi bertujuan agar para pekerja dapat bekerja dengan efektif maka diperlukan dukungan data dan informasi yang dihasilkan sistem menyangkut pelanggan, keadaan pasar, proses internal dan konsekuensi finansial keputusan organisasi.

\section{METODE PENELITIAN}

Metode penelitian adalah investigasi sistematik, terkendali dan empiris terhadap suatu set hipotesis-hipotesis yang dibangun dari struktur teori. Penelitian ini berlandaskan teori-teori yang berhubungan dengan obyek penelitian. Penelitian ini berbentuk studi kasus dengan subjek penelitian adalah Sekolah Tinggi Manajemen Informatika dan Komputer (STMIK) Primakara. Jenis penelitian yang dilakukan berupa research and development dengan metode penelitian kualitatif interpretatif. Research and development dapat didefinisikan sebagai proses atau langkah-langkah untuk mengembangkan suatu produk baru atau menyempurnakan produk yang telah ada, yang dapat dipertanggung jawabkan. Dalam penelitian ini research and development dimanfaatkan untuk menghasilkan model perencanaan strategis sistem informasi kinerja dosen. Penelitian diawali dengan merumuskan permasalahan yang terjadi untuk selanjutnya dilakukan studi literatur terkait dengan permasalahan tersebut. Pengumpulan data penelitian ini dilakukan dengan observasi, wawancara, dan studi dokumentasi terkait dengan kinerja dosen yang berhubungan dengan program studi, penjaminan mutu serta lembaga penelitian dan pengabdian masyarakat. Setelah data terkumpul dilanjutkan dengan pengolahan data dengan teknik statistik deskriptif yang mendeskripsikan, menginterpretasikan dan menjelaskan informasi yang diperoleh dari responden. Pada tahap analisis data menggunakan metode IT Balanced Scorecard untuk menganalisis kinerja dosen dari empat perspektif, yaitu kontribusi perusahaan, kesempurnaan operasional, orientasi pengguna dan orientasi masa depan. Analisis tersebut dijabarkan ke dalam visi, misi dan tujuan strategis. Penjabaran ini untuk melihat keterkaitan antara visi, misi dan tujuan strategis dari STMIK Primakara untuk memperoleh Key Performace Indicator (KPI) pengukuran kinerja dosen. 


\section{HASIL DAN PEMBAHASAN}

Sekolah Tinggi Manajemen Informatika dan Komputer (STMIK) Primakara sebagai salah satu lembaga pendidikan tinggi komputer di propinsi Bali yang berdiri pada tanggal 27 September 2013 dengan izin berdasarkan SK Kementerian Pendidikan dan Kebudayaan Dirjen Pendidikan Tinggi Nomor 458/E/O/2013. STMIK Primakara memiliki tiga Program Studi yaitu S-1 Sistem Informasi. S-1 Sistem Informasi Akuntansi, dan S-1 Teknik Informatika. Sebagai perguruan tinggi yang memfokuskan diri pada bidang technopreneurship, adapun visi dari STMIK Primakara adalah "Menjadi perguruan tinggi unggulan yang melahirkan SDM profesional yang berjiwa technopreneurship."

Untuk pencapaian visi tersebut, STMIK Primakara menerjemahkannya ke dalam misi yaitu :

1. Menyelenggarakan pendidikan di bidang Teknologi Informasi yang berkualitas, inovatif dan mengacu kepada kebutuhan di masa depan dengan tata kelola yang baik (Good University Governance).

2. Menjadi wadah dalam mempersiapkan sumber daya manusia profesional, berkompetensi global, kreatif, memiliki keahlian yang jelas (specialist), memiliki etika yang baik serta berjiwa technopreneurship.

3. Melakukan penelitian dan pengabdian kepada masyarakat yang berbasis pada pengembangan teknologi informasi untuk peningkatan kualitas hidup masyarakat dan daya saing bangsa.

4. Menjalin kerjasama sinergis dengan stakeholder, berperan aktif dan berkonstribusi nyata dalam pengembangan dan penerapan teknologi informasi.

5. Mengembangkan kemampuan berwirausaha di bidang teknologi informasi (technopreneurship) yang memberikan nilai tambah (added value), berkolaborasi dengan komunitas dan menyelenggarakan inkubasi bisnis.

Dari hasil wawancara dan pengamatan yang dilakukan dalam penelitian ini diperoleh informasi mengenai gambaran internal terkait visi, misi, dan tujuan strategis dari STMIK Primakara. Dari tahapan tersebut, diperoleh bahwa STMIK Primakara memiliki beberapa tujuan strategis yang termuat dalam Rencana Strategis Periode 2018-2021. Penelusuran ter- hadap visi, misi dan penjabarannya dalam tujuan strategik diperoleh dalam bentuk tabulasi, seperti pada tabel 4.1.

Tabel 4.1. Tabulasi visi, misi, tujuan startegis

\begin{tabular}{|c|c|c|}
\hline \multicolumn{3}{|c|}{$\begin{array}{l}\text { Visi STMIK Primakara } \\
\text { Menjadi perguruan tinggi unggulan yang melahirkan SDM } \\
\text { profesional yang berjiwa technopreneurship }\end{array}$} \\
\hline \multicolumn{3}{|c|}{$\begin{array}{l}\text { 1.Menyelenggarakan pendidikan di bidang Teknologi } \\
\text { Informasi yang berkualitas, inovatif dan mengacu kepada } \\
\text { kebutuhan di masa depan dengan tata kelola yang baik } \\
\text { (Good University Governance). } \\
\text { 2.Menjadi wadah dalam mempersiapkan sumber daya manusia } \\
\text { profesional, berkompetensi global, kreatif, memiliki } \\
\text { keahlian yang jelas (specialist), memiliki etika yang baik } \\
\text { serta berjiwa technopreneurship. } \\
\text { 3.Melakukan penelitian dan pengabdian kepada masyarakat } \\
\text { yang berbasis pada pengembangan teknologi informasi } \\
\text { untuk peningkatan kualitas hidup masyarakat dan daya saing } \\
\text { bangsa. } \\
\text { 4.Menjalin kerjasama sinergis dengan stakeholder, berperan } \\
\text { aktif dan berkonstribusi nyata dalam pengembangan dan } \\
\text { penerapan teknologi informasi. } \\
\text { 5.Mengembangkan kemampuan berwirausaha di bidang } \\
\text { teknologi informasi (technopreneurship) yang memberikan } \\
\text { nilai tambah (added value), berkolaborasi dengan komunitas } \\
\text { dan menyelenggarakan inkubasi bisnis. }\end{array}$} \\
\hline No & Perspektif IT BSC & \\
\hline 1 & $\begin{array}{l}\text { Kontribusi Organisasi } \\
\text { (Corporate Contribution) }\end{array}$ & Alokasi Dana \\
\hline 2 & $\begin{array}{l}\text { Orientasi pengguna (User } \\
\text { Orientation) }\end{array}$ & $\begin{array}{l}\text { Kepuasan Mahasiswa } \\
\text { Kepuasan Dosen }\end{array}$ \\
\hline 3 & $\begin{array}{l}\text { Keunggulan Operasional } \\
\text { (Operational Excellence) }\end{array}$ & $\begin{array}{l}\text { Kinerja dosen } \\
\text { Inovasi }\end{array}$ \\
\hline 4 & $\begin{array}{l}\text { Orientasi dimasa depan } \\
\text { (Future Orientation) }\end{array}$ & $\begin{array}{l}\text { Penelitian, pengabdian } \\
\text { masyarakat, } \\
\text { pengembangan dosen, } \\
\text { publikasi }\end{array}$ \\
\hline
\end{tabular}

Berdasarkan hasil tabulasi terhadap visi, misi, dan penjabaran dalam tujuan strategik, kemudian disusun hubungan keterkaitan masingmasing perspektif dengan tujuan strategis seperti pada tabel 4.2 . 
Tabel 4.2. Hubungan IT Balanced Scorecard dengan tujuan startegis

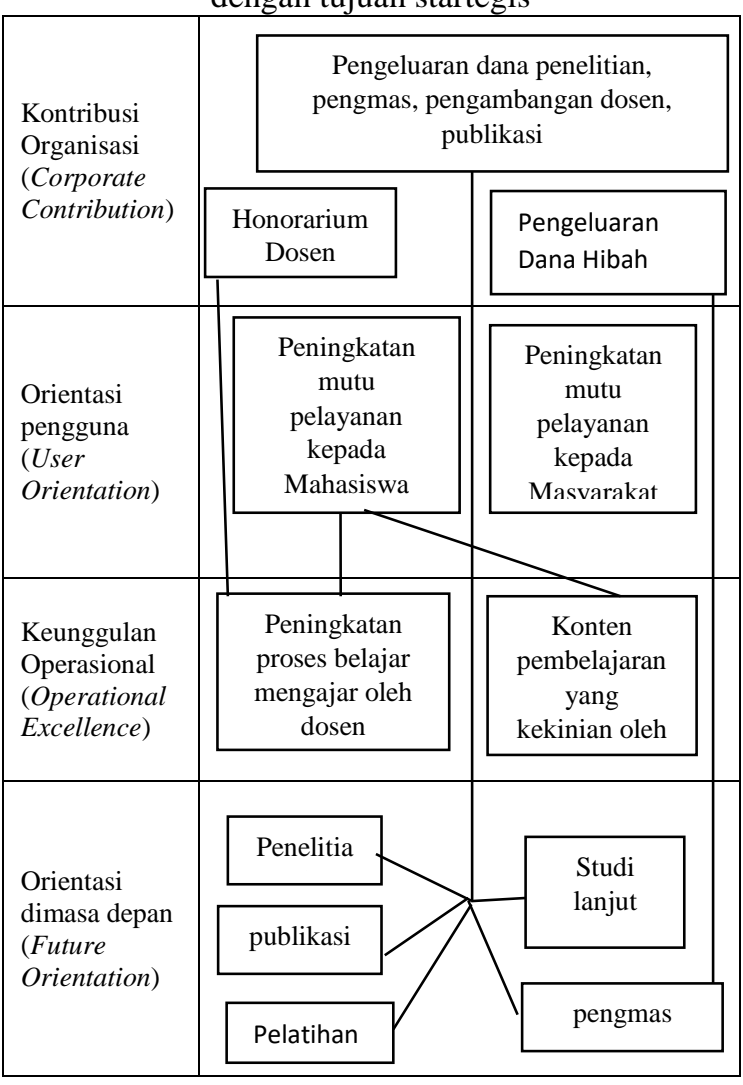

Setelah diperoleh keterkaitan antara prespektif IT Balanced Scorecard dengan tujuan staregis, kemudian diperoleh sasaran startegis dan Key Performance Indicator (Kpi) kinerja dosen seperti tabel 4.3 berikut ini :

Tabel 4.3. Sasaran Strategis dan Key Performance Indicator

\begin{tabular}{|c|c|c|}
\hline Perspektif & $\begin{array}{l}\text { Sasaran } \\
\text { Stretegis }\end{array}$ & $\begin{array}{c}\text { Key Performance } \\
\text { Indicator }\end{array}$ \\
\hline $\begin{array}{l}\text { Kontribusi } \\
\text { Organisasi } \\
\text { (Corporate } \\
\text { Contribu } \\
\text { tion) }\end{array}$ & $\begin{array}{l}\text { 1.Alokasi ang- } \\
\text { garan honora- } \\
\text { rium dosen } \\
\text { 2.Alokasi ang- } \\
\text { garan untuk } \\
\text { penelitian, } \\
\text { pengmas, } \\
\text { pengembang } \\
\text { an dosen, pu- } \\
\text { blikasi } \\
\text { 3.Dana hibah } \\
\text { internal/ekste } \\
\text { rnal }\end{array}$ & $\begin{array}{l}\text { 1.Jumlah dana ho- } \\
\text { norium dosen da- } \\
\text { lam berkegiatan } \\
\text { 2.Jumlah dana pe- } \\
\text { nelitian dan pen- } \\
\text { gabdian. } \\
\text { 3.Jumlah dana yang } \\
\text { dialokasikan } \\
\text { untuk pengem- } \\
\text { bangan kom- } \\
\text { petensi dosen } \\
\text { 4.Jumlah dana yang } \\
\text { dialokasikan un- } \\
\text { tuk publikasi }\end{array}$ \\
\hline Orientasi & 1.Peningkatan & 1.Evaluasi Ke- \\
\hline
\end{tabular}

\begin{tabular}{|c|c|c|}
\hline $\begin{array}{l}\text { pengguna } \\
\text { (User } \\
\text { Orien- } \\
\text { tation) }\end{array}$ & \begin{tabular}{|l} 
pelayanan \\
kepada \\
mahasiswa. \\
2.Peningkatan \\
pelayanan \\
kepada \\
masyarakat
\end{tabular} & $\begin{array}{l}\text { puasan Maha- } \\
\text { siswa } \\
\text { 2.Keseuaian pem- } \\
\text { bingan akademik } \\
\text { 3.Keterliban se- } \\
\text { bagai narasumber } \\
\text { dalam semi- } \\
\text { nar/lokarya }\end{array}$ \\
\hline $\begin{array}{c}\text { Keunggulan } \\
\text { Operasional } \\
\text { (Operation } \\
\text { al } \\
\text { Excellence) }\end{array}$ & $\begin{array}{l}\text { 1.Peningkatan } \\
\text { proses belajar } \\
\text { mengajar oleh } \\
\text { dosen } \\
\text { 2. Konten } \\
\text { pembelajaran } \\
\text { yang kekinian } \\
\text { oleh dosen }\end{array}$ & $\begin{array}{l}\text { 1.Prosentase ke- } \\
\text { hadiran dosen } \\
\text { sesuai jadwal, } \\
\text { 2.Prosentasse mulai } \\
\text { dan selesai per- } \\
\text { kuliahan tepat } \\
\text { waktu. } \\
\text { 3.Ketersediaan RPS } \\
\text { sesuai dengan } \\
\text { matakuliah yang } \\
\text { diampu. } \\
\text { 4. Keseuaian RPS } \\
\text { dengan BAP } \\
\text { 5.Pengumpulan } \\
\text { Soal Ujian yang } \\
\text { tepat waktu. } \\
\text { 6.Pengumpulan } \\
\text { nilai mahasiswa } \\
\text { yang tepat waktu. } \\
\text { 7.Pemanfaatan e- } \\
\text { lerning dalam } \\
\text { pembelajaran }\end{array}$ \\
\hline $\begin{array}{l}\text { Orientasi } \\
\text { dimasa de- } \\
\text { pan (Future } \\
\text { Orien } \\
\text { tation) }\end{array}$ & $\begin{array}{l}\text { 1.Penelitian } \\
\text { 2.Pengabdian } \\
\text { masyarakat } \\
\text { 3.Publikasi } \\
\text { Ilmiah } \\
\text { 4.Studi lanjut } \\
\text { dosen } \\
\text { 5.Pengemban } \\
\text { gan kompe- } \\
\text { tensi }\end{array}$ & $\begin{array}{l}\text { 1.Jumlah penelitian } \\
\text { yang dilakukan } \\
\text { dalam } 1 \text { semester } \\
\text { 2.Prosentase } \\
\text { penelitian dosen } \\
\text { yang mendapat- } \\
\text { kan hak paten } \\
\text { (HAKI) } \\
\text { 3.Prosentase jum- } \\
\text { lah penelitian } \\
\text { yang diperoleh } \\
\text { dari eksternal } \\
\text { 4.Jumlah pengab- } \\
\text { dian yang dila- } \\
\text { kukan dan 1 } \\
\text { tahun } \\
\text { 5.Keterlibatan ma- } \\
\text { hasiswa dalam } \\
\text { penelitian dan } \\
\text { pengabdian } \\
\text { masyarakat } \\
\text { 6.Rasio penelitian } \\
\text { dan pengabdian } \\
\text { masyarakat oleh } \\
\text { dosen yang di- } \\
\text { terbitkan dalam } \\
\text { jurnal terakre- } \\
\text { ditasi. } \\
\text { 7.Partisipasi dosen } \\
\end{array}$ \\
\hline
\end{tabular}




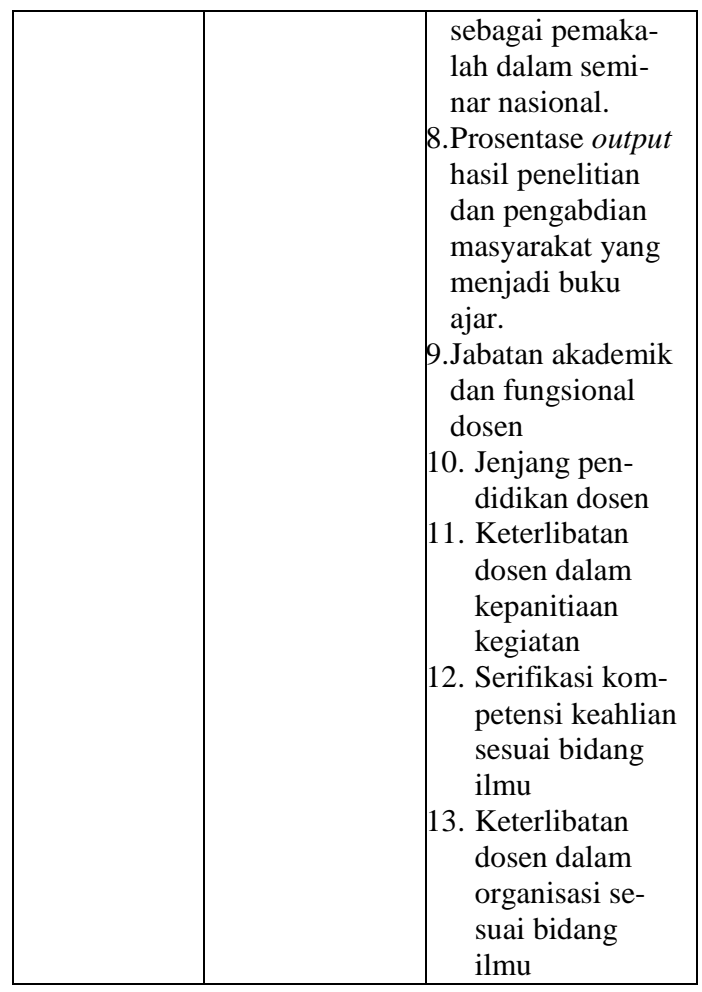

\section{SIMPULAN}

Dari penelitian yang telah dilakukan adalah rencana strategis sistem informasi pengukuran kinerja dosen dengan IT balanced scorecard di STMIK Primakara dalam perspektif kontribusi organisasi memiliki 3 sasaran strategis, yaitu honorarium dosen, anggaran untuk penelitian, pengmas, pengembangan dosen, publikasi, dana hibah internal/eksternal. Dalam perspektif orientasi pengguna memiliki 2 sasaran strategis, yaitu peningkatan pelayanan kepada mahasiswa, peningkatan pelayanan kepada masyarakat. Dalam perspektif keunggulan operasional memiliki 2 sasaran startegis, yaitu peningkatan proses belajar mengajar oleh dosen, konten pembelajaran yang kekinian oleh dosen. Dalam perspektif orientasi dimasa depan memiliki memiliki 5 sasaran startegis, yaitu penelitian, pengabdian masyarakat, publikasi ilmiah, studi lanjut dosen, pengembangan kompetensi dosen. Serta menghasilkan 27 key performance indicator yang akan digunakan sebagai pengukuran kinerja dosen di STMIK Primakara

\section{DAFTAR PUSTAKA}

[1] Agustin, YH. Kurniawan, H. 2015. Sistem Pendukung Keputusan Penilaian Kinerja Dosen Menggunakan Metode Weighted Product (Studi Kasus : Stmik Pontianak). Seminar Nasional Informatika 2015

[2] Rochim, A.F. 2014., Jurnal Perencanaan Strategis Sistem Informasi Perguruan Tinggi (Studi Kasus di Universitas Diponegoro Semarang). directory.umm.ac.id/SIP/binus.pdf Diakses pada 8 Pebruari 2017

[3] Agung, AAG. Yuniar, I. 2014. Desain Indikator Dan Implementasi Penilaian Kinerja Dosen Pada Sistem Informasi. Seminar Nasional Sistem Informasi Indonesia, 22 September 2014.

[4] _ 2009. Pedoman Penilaian Kinerja Dosen. Fakultas Ilmu Pendidikan Universitas Pendidikan Indonesia

[5] Turban. Efrain., Valonino, Linda. 2012. Information Technology for Management. 8th Edition. John Wiley \& Sons,Inc.

[6] Sensuse, D.I dan H. Sopryadi 2008, Perencanaan Strategis Sistem Dan Teknologi Informasi Pada St. Ignatius Education Center Palembang. Jurnal Ilmiah STIMIK GI MDP. Volume 4 Nomor 3, Oktober 2008

[7] Ward, J. and J. Pepard 2002. Strategic Planning for Information Systems (third ed.). Cranfield School of Management Cranfield, Bedfordshire, UK

[8] O'Brein JA. 2008. Pengantar Sistem Informasi Perspektif Bisnis dan Manajerial. Jakarta. Salemba Empat.

[9] Juliana.EP, Linawati, Wirastuti, 2015. Perencanaan Strategis Sistem Informasi Promosi pada UPBJJ-UT Denpasar. Majalah Ilmiah Teknik Elektro. Vol 14/No.1/2015. 
[10] Nurjaya, W.W.K, 2014. Model Strategic Planning For Information System Menggunakan Balanced Scorecard Pada Universitas Komputer Bandung. Majalah Ilmiah UNIKOM Vol.7, No. 1

[11] Wedhasmara, A., 2014, Langkah-Langkah Perencanaan Strategis Sistem Informasi Dengan Menggunakan Metode Ward dan Pepard. Jurnal Sistem Informasi Univ. Sriwijaya.

[12] Sirait, A. 2010., Panduan pengelolaan Kinerja Berbasis Balanced Scorecard di Lingkungan Kementerian Keuangan. Pusat analisis dan harmonisasi Kebijakan Sekretriat Jenderal Kementerian Keuangan.

[13] Kaplan, R.S. 2009, Working Paper Conceptual Foundations of the Balanced Scorecard. Working Paper 10-074. Harvard Business School, Harvard University.

[14] Sipayung, F. 2009, Balanced Scorecard: Pengukuran Kinerja Perusahaan dan Sistem manajemen Strategis. Jurnal Manajemen Bisnis Universitas Sumatra Utara, Volume 2, Nomor 1, Januari 2009: 7 - 14.

[15] Syarifudin, G. 2013. Perencanaan Strategis Sistem Informasi Kinerja dengan Menggunakan IT Balanced Scorecard. Jurnal Ilmiah SISFOTENIKA, Vol. 3, No. 1, Januari 2013

[16] Jogiyanto dan Wily Abdillah, 2011. Sistem Tatakelola Teknologi Informasi. Yogyakarta: Penerbit Andi Offset.

[17] Keyes. Jesica. 2005. Implementing the IT Balanced Scorcard Aligning IT with Corporate Strategy. Taylon \& Francis Group.

[18] Solechan, A. 2015. Tata Kelola Kinerja Teknologi Informasi Menggunakan II Balanced Scorecard (Studi Pada Stmik Provisi Semarang). Jurnal Teknologi Informasi dan Komunikasi, ISSN:20870868, Volume 6 Nomor 2 September 2015. Semarang. 